\title{
Chemical vapour deposition of Group Vb metal phosphide thin films
}

\author{
C. S. Blackman, ${ }^{a}$ C. J. Carmalt, ${ }^{a}$ S. A. O'Neill, ${ }^{a}$ I. P. Parkin, ${ }^{* a}{ }^{a}$ K. C. Molloy, ${ }^{b}$ and L. Apostolico ${ }^{b}$ \\ ${ }^{a}$ Department of Chemistry, University College London, 20 Gordon Street, London, WC1H 0AJ, England. Tel: \\ +44(0)2076794669; E-mail: i.p.parkin@ucl.ac.uk \\ ${ }^{b}$ Department of Chemistry, University of Bath, Claverton Down, Bath, BA2 4JH, England. E-mail: \\ k.c.molloy@bath.ac.uk
}

\section{This submission was created using the RSC Article Template (DO NOT DELETE THIS TEXT) (LINE INCLUDED FOR SPACING ONLY - DO NOT DELETE THIS TEXT)}

The atmospheric pressure chemical vapour deposition (APCVD) reaction of $\mathrm{VCl}_{4}$ and $\mathrm{VOCl}_{3}$ with cyclohexylphosphine at substrate temperatures of $600^{\circ} \mathrm{C}$ deposits thin films of amorphous vanadium phosphide. The films are black/gold, hard, chemically resistant and conductive. The APCVD reaction of $\mathrm{MCl}_{5}$ (where $\mathrm{M}=\mathrm{Nb}$ or Ta) with cyclohexylphosphine at $500{ }^{\circ} \mathrm{C}-600{ }^{\circ} \mathrm{C}$ deposits films of crystalline $\beta$-MP and at $400{ }^{\circ} \mathrm{C}-450{ }^{\circ} \mathrm{C}$ amorphous films of stoichiometry MP are formed. The MP films are metallic, conductive, adherent and chemically resistant.

\section{Introduction}

Transition metal phosphides form an interesting series of materials with a number of potential applications. Niobium(III) phosphide $(\mathrm{NbP})$ is metallic, as hard as high carbon steel ${ }^{1}$ and is resistant to attack by oxygen, sulfur dioxide and hydrogen sulfide up to $600{ }^{\circ} \mathrm{C}^{2}$. Tantalum(III) phosphide (TaP) is also metallic, very dense $\left(\sim 11 \mathrm{~g} / \mathrm{cm}^{3}\right)^{1}$ and even more chemically resistant than $\mathrm{NbP} .^{2}$ It has been used as a diffusion barrier layer in semiconductor devices. ${ }^{3}$ Similarly, vanadium(III) phosphide (VP) is a hard, metallic conductor. ${ }^{1}$

Bulk transition metal phosphides can be synthesised by direct elemental combination ${ }^{4}$ or from reaction of the anhydrous metal halide with $\mathrm{Na}_{3} \mathrm{P}{ }^{5}$ Thin films of group $\mathrm{Vb}$ nitrides have been prepared from reaction of the metal chloride with nitrogen and hydrogen $^{6,7}$ or ammonia (with or without hydrogen). ${ }^{8,9}$ Thin films of several transition metal phosphides have been synthesised from the reaction of metal chlorides with $\mathrm{PCl}_{3}$ and hydrogen at temperatures above $850{ }^{\circ} \mathrm{C} .{ }^{2}$ The drawback with these methods are the high process temperatures required and the phosphorus analogue of ammonia, phosphine $\left(\mathrm{PH}_{3}\right)$, is a pyrophoric, extremely toxic gas. Winter et al have demonstrated a low pressure route $\left(400-600{ }^{\circ} \mathrm{C}\right)$ to thin $\mathrm{NbP}$ films using a single-source precursor formed from the reaction of niobium $(\mathrm{V})$ chloride and cyclohexylphosphine $\left(\mathrm{Cy}^{\text {hex }} \mathrm{PH}_{2}\right)$ but this precursor showed significant decomposition at its sublimation temperature. ${ }^{10}$ It has also been shown that the reaction of a metal chloride with a primary organophosphine $\left(\mathrm{RPH}_{2}\right)$ provides a readily accesible low temperature route to metal phosphides ${ }^{11-14}$ and recently this has been demonstrated for the production of $\beta$ $\mathrm{TaP}$ from the reaction of $\mathrm{TaCl}_{5}$ with $\mathrm{Cy}^{\text {hex }} \mathrm{PH}_{2}$. ${ }^{15}$

We have shown that TiP films can be made from the APCVD reaction of $\mathrm{TiCl}_{4}$ and $\mathrm{Cy}^{\text {hex }} \mathrm{PH}_{2}{ }^{12}$ Here we report the first APCVD study of group $\mathrm{Vb}$ phosphides from the reaction of volatile halide precursors and $\mathrm{Cy}^{\text {hex }} \mathrm{PH}_{2}$. This paper also describes the effect of process conditions on the resultant films. We show that $\mathrm{NbP}$ and $\mathrm{TaP}$ films are metallic, hard and chemically resistant.

\section{Experimental}

Nitrogen $(99.99 \%)$ was obtained by BOC and used as supplied. Coatings were obtained on SiCO coated float-glass (the SiCO is a barrier layer to stop diffusion of ions from the glass into the CVD produced film). APCVD experiments were conducted on $90 \mathrm{~mm} \times 45 \mathrm{~mm} \times 4 \mathrm{~mm}$ pieces of glass using a horizontal bed cold wall APCVD reactor. The glass was cleaned prior to use by washing with petroleum ether $\left(40-60{ }^{\circ} \mathrm{C}\right)$, then propan-2-ol and subsequently dried in air. A graphite block containing a Whatman cartridge heater was used to heat the glass substrate. The temperature of the substrate was monitored by a Pt-Rh thermocouple. Measurements indicated that temperature gradients of less than $25{ }^{\circ} \mathrm{C}$ at $500{ }^{\circ} \mathrm{C}$ were noted across the glass substrates. The rig was designed so that two independent gas lines could be utilised. All gas handling lines, regulators and flow valves were made of stainless steel and were $1 / 4$ " internal diameter except for the inlet to the mixing chamber and the exhaust line from the apparatus that were $1 / 2$ " i.d. In these experiments three gas lines were used. Gases came directly from a cylinder and were preheated by passing along $2 \mathrm{~m}$ lengths of stainless steel tubing which was curled and inserted inside a tube furnace. The temperatures of all the gas inlet lines were monitored by $\mathrm{Pt}-\mathrm{Rh}$ thermocouples and Eurotherm heat controllers. Vanadium(IV) chloride and vanadium(V) oxytrichloride (99\%) were purchased from the Aldrich Chemical Co. and niobium(V) chloride $(99+\%)$, tantalum(V) chloride (99.9\%), cyclohexylphosphine ( $\geq 97 \%)$, dicyclohexylphosphine (98\%) and tricyclohexylphosphine (97\%) from Strem Chemicals. The chemicals were used as supplied and placed into stainless steel bubblers. Tristrimethylsilylphosphine $\left(\left(\mathrm{Me}_{3} \mathrm{Si}\right)_{3} \mathrm{P}\right)$ was synthesised according to a modified version of the literature procedure $\left({ }^{31} \mathrm{P}\{\mathrm{H}\}\right.$ NMR showed only a singlet at $\delta-251 \mathrm{ppm}$ $\left(\left(\mathrm{Me}_{3} \mathrm{Si}\right)_{3} \mathrm{P}\right)$ indicating purity $\left.>98 \%\right)$ and was similarly placed into a stainless steel bubbler. ${ }^{16}$ The bubblers were heated using a heating jacket and the vapour generated introduced into the gas streams by passing hot nitrogen gas through the bubblers. Streams of the precursors (highly diluted with nitrogen) were mixed by using concentric pipes of $1 / 4$ " and 1/2" diameter, the inner pipe being $3 \mathrm{~cm}$ shorter than the outer pipe. The concentric pipes were attached directly to the mixing chamber of the coater. Gas flows were adjusted using suitable regulators and flow controllers. The exhaust from the reactor was vented directly into the extraction system of a fume cupboard. All of the apparatus was baked out with nitrogen at $150{ }^{\circ} \mathrm{C}$ for 60 minutes before the runs. Suitable two-way and three way valves (rated to $200{ }^{\circ} \mathrm{C}$ ) allowed the nitrogen lines to be diverted into or away from the bubbler. Deposition experiments were conducted by heating the horizontal bed reactor and the bubbler to the required temperatures before diverting the nitrogen line through the bubbler and hence to the reactor. At the end of the deposition the bubbler-lines were closed and only nitrogen passed over the substrate. The glass substrate was allowed to cool with the graphite block to $\mathrm{ca} 150{ }^{\circ} \mathrm{C}$ before it was removed. Coated substrates were handled and stored in air. The large coated glass sample was broken up for subsequent analysis by XPS, EDAX, 
SEM, Electron Probe Microanalysis (EPMA), transmission / reflectance and UV/VIS studies. Larger pieces of glass were used for sheet resistance, glancing angle X-ray powder, infrared, contact angle, photo-catalysis and Scotch tape tests.

X-ray powder diffraction patterns were measured on a Siemens D5000 diffractometer using monochromated $\mathrm{CuK}_{\alpha 1}$ radiation $\left(\lambda_{1}\right.$ $=1.5406 \AA$ ) utilising a Position Sensitive Detector (PSD). The diffractometer was used in glancing incident geometry $\left(5^{\circ}\right)$. Data manipulation was performed using Bruker EVA software and samples were indexed using Unit Cell and compared to database standards. SEM/EDAX was obtained on a Phillips XL30 ESEM using Oxford Instruments instrument control and Inca Wave analytical software. Electron Probe Micro-Analysis (EPMA) was obtained on a JEOL EMA and referenced against appropriate elemental standards. X-ray photoelectron spectra were recorded with a VG ESCALAB 220i XL instrument using focussed (300 $\mu \mathrm{m}$ spot) monochromatic $\mathrm{Al}-\mathrm{K}_{\alpha}$ radiation at a pass energy of 20 $\mathrm{eV}$. Scans were acquired with steps of $50 \mathrm{meV}$. A flood gun was used to control charging and the binding energies were referenced to an adventitious C $1 \mathrm{~s}$ peak at $284.8 \mathrm{eV}$. Depth profile measurements were obtained by using argon beam sputtering.

UV/VIS spectra were recorded in the range 200-1100 nm using a Helios double beam instrument. Reflectance spectra were recorded between 300 and $1200 \mathrm{~nm}$ by a Zeiss minature spectrometer. Measurements were standardised relative to a rhodium mirror. Electrical conductivity was determined by 4 probe measurement. Hardness scratch tests were conducted with felt pads, brass stylus and a stainless steel stylus.

Caution. It should be noted that the dual source APCVD reaction of $\mathrm{MCl}_{\mathrm{x}}$ and $\mathrm{Cy}{ }^{\text {hex }} \mathrm{PH}_{2}$ could conceivably proceed through a $\mathrm{PH}_{3}$ intermediate. $\mathrm{PH}_{3}$ is extremely toxic and can combine explosively with air. Care should be taken to conduct all experiments behind a blast shield and to ventilate to a fume cupboard the exhaust gases from the reactor.

\section{Results}

The conditions for the reaction of $\mathrm{NbCl}_{5}$ and $\mathrm{TaCl}_{5}$ with $\mathrm{Cy}^{\text {hex }} \mathrm{PH}_{2}$ are shown in Table 1 . The metal halide/phosphine ratio shown is the gas phase ratio of moles $\mathrm{MCl}_{5} /$ moles $\mathrm{Cy}^{\text {hex }} \mathrm{PH}_{2}$ calculated from vapour pressure data and flow rates. However, the conditions under which the metal halide bubblers were operated, i.e. at temperatures below the solids melting point and with high $\mathrm{N}_{2}$ flow rates, would cause non-equilibrium conditions. Therefore the values shown are an approximate guide to the gas phase molar ratio only. The conditions for the reaction of vanadium precursors $\left(\mathrm{VCl}_{4}\right.$ and $\left.\mathrm{VOCl}_{3}\right)$ with various phosphines $\left(\mathrm{Cy}^{\text {hex }} \mathrm{PH}_{2}, \mathrm{Cy}^{\text {hex }}{ }_{2} \mathrm{PH}, \mathrm{Cy}^{\text {hex }}{ }_{3} \mathrm{P}\right.$ and $\left.\left(\mathrm{Me}_{3} \mathrm{Si}\right)_{3} \mathrm{P}\right)$ are shown in Table 2. No vapour pressure data was available for $\mathrm{Cy}_{2}^{\text {hex }}{ }_{2} \mathrm{PH}, \mathrm{Cy}^{\text {hex }}{ }_{3} \mathrm{P}$ and $\left(\mathrm{Me}_{3} \mathrm{Si}\right)_{3} \mathrm{P}$. To ensure that the phosphine component was in excess the vanadium precursor bubbler temperature was lowered and run times extended to compensate for the resultant lower molar flow rates relative to reaction with $\mathrm{Cy}^{\text {hex }} \mathrm{PH}_{2}$.

\subsection{APCVD of $\mathrm{NbCl}_{5}$ and $\mathrm{Cy}^{\text {hex }} \mathrm{PH}_{2}$}

The CVD reaction of $\mathrm{NbCl}_{5}$ and $\mathrm{Cy}^{\text {hex }} \mathrm{PH}_{2}$ at $600{ }^{\circ} \mathrm{C}$ with a notional gas-phase $\mathrm{Nb} / \mathrm{P}$ ratio of $1 / 400000$ (Table 1) produced films that covered the entire substrate. The films were opaque and generally silver and highly reflective. However half-way from the front of the substrate, extending towards the back and localised in a central 'strip' the films were discoloured, appearing more matt and with a noticeable black colouration (Figure 1).

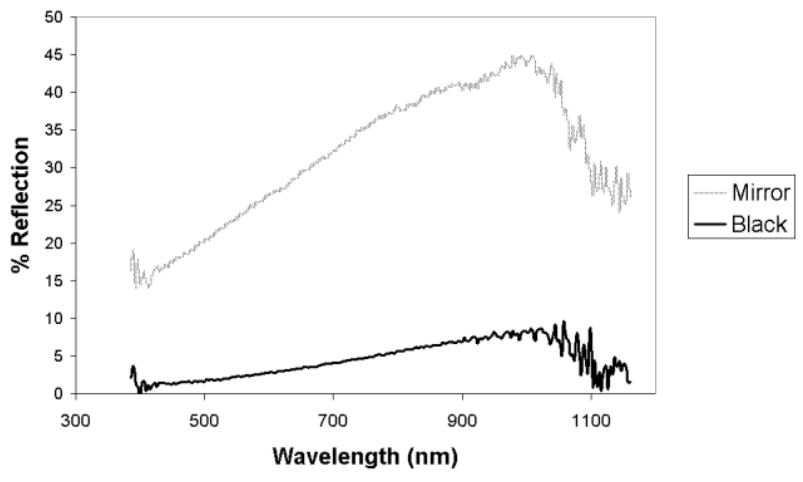

Fig. 1 Comparison of reflection spectra of mirror and black regions of $\beta$ NbP sample produced at $600{ }^{\circ} \mathrm{C}$.

There was no noticeable change in composition in this region compared to the silver mirror region and no measurable increase in carbon contamination using EDAX. XRD showed the only crystalline phase present in each region was $\beta-\mathrm{NbP}$ with unit cell $a=3.30(2) \AA, c=11.6(2) \AA$ (literature $a=3.325 \AA, c=11.38$ $\AA$ ). ${ }^{17}$ It was concluded that the black strip is most likely due to very rapid film growth and is most probably due to aggregation of particulates in this region. EDAX indicated that the average metal/phsophorus composition across the whole surface was $\mathrm{NbP}_{1.3}$. The high phosphorus reading may be misleading because breakthrough to the underlying glass substrate was observed and the silicon line from the glass is almost coincident with the phosphorus line in the EDAX spectrum causing difficulties in accurately quantifying these elements when they occur together. To examine this more closely an EPMA spectrum was obtained of the mirror portion of one film. The film was very slightly phosphorus rich $\left(\mathrm{NbP}_{1.1}\right)$ and even across the entire surface and had undetectable chlorine contamination.

XPS analysis of the mirror-like part of the film deposited at a substrate temperature of $600{ }^{\circ} \mathrm{C}$ revealed a surface with two phosphorus environments. The major $\mathrm{P} 2 \mathrm{p}$ ionisation was observed at $128.6 \mathrm{eV}$ which is indicative of the formation of a transition metal phosphide ${ }^{10,18}$ although a minor peak was observed at $133.8 \mathrm{eV}$, which has been attributed to phosphate ${ }^{10}$. The major surface $\mathrm{Nb} 3 \mathrm{~d}_{5 / 2}$ ionisation was observed at $203.2 \mathrm{eV}$ identified previously as being associated with $\mathrm{NbP}^{10}$. A very minor $\mathrm{Nb} 3 \mathrm{~d}_{3 / 2}$ ionisation appeared at $\sim 210 \mathrm{eV}$ presumably from niobium oxide or niobium phosphate. A broad surface $\mathrm{O} 1 \mathrm{~s}$ ionisation was centred on $530.6 \mathrm{eV}$ suggesting both phosphate and oxide were present. ${ }^{18}$ No peak for chlorine was observed. After argon ion etching (30 s) no peaks associated with oxygen or carbon were observed and the only $\mathrm{P} 2 \mathrm{p}$ and $\mathrm{Nb} 3 \mathrm{~d}_{5 / 2}$ ionisations remaining were at $128.6 \mathrm{eV}$ and $203.2 \mathrm{eV}$ respectively. This suggests that the oxygen contamination at the surface is a result of post-reaction oxidation and not as a result of the deposition process. The results also indicate considerably less oxygen contamination is present than that found using a single-source precursor to deposit $\mathrm{NbP}$ (combined $\mathrm{C}, \mathrm{O}$ and $\mathrm{Cl}$ contamination $\sim 10$ at. \%). ${ }^{10}$ This may be as a result of the faster deposition rate and greater reactant flux associated with atmospheric pressure CVD than used in the comparable singlesource low pressure CVD. ${ }^{10}$

Film thickness was measured by cleaving the film at the centre of the substrate and using SEM to view the film end-on. The films grown at $600{ }^{\circ} \mathrm{C}$ from $\mathrm{NbCl}_{5}$ and $\mathrm{Cy}^{\text {hex }} \mathrm{PH}_{2}$ were determined to be between 250-300 $\mathrm{nm}$ thick (growth rate $\sim 90$ $\mathrm{nm} / \mathrm{min}$ ). The resistivity of the films varied between 2000 and $3000 \mu \Omega \mathrm{cm}^{-1}$. This compares well with the literature value for bulk NbP of $1700 \mu \Omega \mathrm{cm}^{-1}$. ${ }^{1}$ Upon cooling to $-197{ }^{\circ} \mathrm{C}$ the film exhibited a $50 \%$ drop in resistivity. The values show 
Table $1 \mathrm{CVD}$ process conditions for the reaction of $\mathrm{MCl}_{5}$ (where $\mathrm{M}=\mathrm{Nb}$ or Ta) with $\mathrm{Cy}^{\text {hex }} \mathrm{PH}_{2}$

\begin{tabular}{|c|c|c|c|c|c|c|c|c|c|c|}
\hline $\begin{array}{l}\text { Metal halide } \\
\text { precursor }\end{array}$ & $\begin{array}{l}\text { Metal halide } \\
\text { bubbler temp. } \\
\left({ }^{\circ} \mathrm{C}\right)\end{array}$ & $\begin{array}{l}\text { Metal halide } \\
\text { bubbler } \mathrm{N}_{2} \text { flow } \\
\text { rate }(1 / \mathrm{min})\end{array}$ & $\begin{array}{l}\text { Phosphine } \\
\text { bubbler temp. } \\
\left({ }^{\circ} \mathrm{C}\right)\end{array}$ & $\begin{array}{l}\text { Phosphine } \\
\text { bubbler } \mathrm{N}_{2} \text { flow } \\
\text { rate }(1 / \mathrm{min})\end{array}$ & $\begin{array}{l}\text { Metal halide/ } \\
\text { phosphine ratio } \\
\text { (mol) }\end{array}$ & $\begin{array}{l}\text { Substrate } \\
\text { temp. }\left({ }^{\circ} \mathrm{C}\right)\end{array}$ & $\begin{array}{l}\text { Run } \\
\text { Time } \\
\text { (min) }\end{array}$ & $\begin{array}{l}\text { Thickness } \\
\text { (nm) }\end{array}$ & $\begin{array}{l}\text { EDAX } \\
(\mathrm{M} / \mathrm{P} \\
\text { ratio) }\end{array}$ & XRD \\
\hline $\mathrm{NbCl}_{5}$ & 150 & 2.0 & 120 & 0.3 & $1 / 400000$ & 600 & 3 & $250-300$ & 0.8 & $\beta-\mathrm{NbP}$ \\
\hline $\mathrm{NbCl}_{5}$ & 150 & 2.0 & 120 & 0.3 & $1 / 400000$ & 550 & 3 & $160-200$ & 0.9 & $\beta-\mathrm{NbP}$ \\
\hline $\mathrm{NbCl}_{5}$ & 150 & 2.0 & 120 & 0.3 & $1 / 400000$ & 500 & 3 & $50-80$ & 0.8 & a \\
\hline $\mathrm{NbCl}_{5}$ & 150 & 2.0 & 120 & 0.3 & $1 / 400000$ & 450 & 3 & b & 0.7 & a \\
\hline $\mathrm{NbCl}_{5}$ & 150 & 2.0 & 120 & 0.3 & $1 / 400000$ & 400 & 3 & c & $\mathrm{c}$ & c \\
\hline $\mathrm{NbCl}_{5}$ & 190 & 2.0 & 100 & 0.3 & $1 / 180$ & 550 & 3 & d & 0.8 & $\beta-\mathrm{NbP}$ \\
\hline $\mathrm{NbCl}_{5}$ & 190 & 2.0 & 80 & 0.3 & $1 / 50$ & 550 & 3 & d & 0.9 & $\beta-\mathrm{NbP}$ \\
\hline $\mathrm{NbCl}_{5}$ & 190 & 2.0 & 60 & 0.3 & $1 / 12$ & 550 & 3 & d & 0.8 & $\beta-\mathrm{NbP}$ \\
\hline $\mathrm{TaCl}_{5}$ & 160 & 2.0 & 130 & 0.1 & $1 / 50000$ & 600 & 3 & $370-400$ & 0.7 & $\beta-\mathrm{TaP}$ \\
\hline $\mathrm{TaCl}_{5}$ & 160 & 2.0 & 130 & 0.1 & $1 / 50000$ & 550 & 3 & $280-300$ & 0.8 & $\beta-\mathrm{TaP}$ \\
\hline $\mathrm{TaCl}_{5}$ & 160 & 2.0 & 130 & 0.1 & $1 / 50000$ & 400 & 3 & & a & \\
\hline
\end{tabular}

${ }^{a}$ Amorphous.

${ }^{b}$ Film too thin for accurate measurement (less than $30 \mathrm{~nm}$ ).

${ }^{\mathrm{c}}$ Film too thin for practical analysis (less than $~ 10 \mathrm{~nm}$ ).

${ }^{\mathrm{d}}$ Not determined.

that the thin film NbP is a metallic conductor at the temperatures examined.

The films formed at $550{ }^{\circ} \mathrm{C}(\mathrm{Nb} / \mathrm{P}$ precursor gaseous molar ratio $1 / 400000)$ were opaque and entirely silver and mirror-like with no discolouration observed. The average composition observed using EDAX was $\mathrm{NbP}_{1.1}$ and glancing angle XRD revealed the only crystalline phase was $\beta-\mathrm{NbP}(a=3.32(3) \AA$, $c=11.7(3) \AA)$.

The EPMA results (Figure 2) showed chlorine contamination was below detection limits and the film had an even composition across a distance of $5000 \mu \mathrm{m}$ of $\mathrm{NbP}_{1.1}$. The film thickness measured varied between 160 and $200 \mathrm{~nm}$ at the centre of the substrate $(\sim 60 \mathrm{~nm} / \mathrm{min}$ growth rate) and room temperature film resistivities were $5000-6000 \mu \Omega \mathrm{cm}^{-1}$.

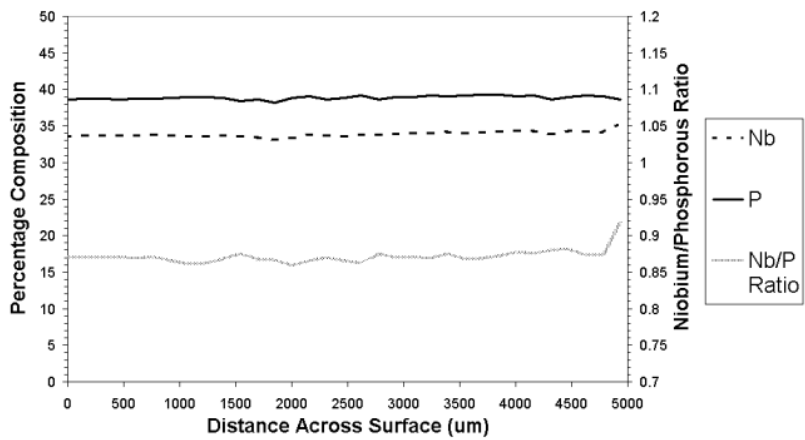

Fig. 2 EPMA composition of $\mathrm{NbP}$ film deposited at $550^{\circ} \mathrm{C}$.

Films formed at $500{ }^{\circ} \mathrm{C}(\mathrm{Nb} / \mathrm{P}$ precursor gaseous molar ratio 1/400000) were similarly silver and mirror-like although not completely opaque. The average niobium/phosphorus composition found by EDAX was $\mathrm{NbP}_{1.3}$ with almost undetectable levels of chlorine contamination. The films were $\mathrm{X}$ ray amorphous as deposited, between 50 and $80 \mathrm{~nm}$ thick at the centre of the substrate $(\sim 20 \mathrm{~nm} / \mathrm{min}$ growth rate $)$ and had resistivities of the order of $6000 \mu \Omega \mathrm{cm}^{-1}$.

Total coverage of the substrate also took place at a substrate temperature of $450{ }^{\circ} \mathrm{C}$, with the films being noticeably thinner (optical transmission) although still highly reflective. Sheet resistance measurements showed that the films were metallic but film thickness measurement proved impossible by SEM. These films were also X-ray amorphous. At $400{ }^{\circ} \mathrm{C}$ deposition was observed but it was highly localised and too thin for practical analysis.
The change in growth rate with temperature $(90 \mathrm{~nm} / \mathrm{min}$ at 600 ${ }^{\circ} \mathrm{C}, 60 \mathrm{~nm} / \mathrm{min}$ at $550{ }^{\circ} \mathrm{C}$ and $20 \mathrm{~nm} / \mathrm{min}$ at $500{ }^{\circ} \mathrm{C}$ ) and the complete surface coverage indicates that the reaction is surface rate limited under the conditions employed. Due to the glass substrates used (softening temperature $\sim 600{ }^{\circ} \mathrm{C}$ ) it was not possible to examine the temperautre required for mass transport limited growth to be exhibited under the precursor flow rates used.

An investigation of the effect of the precursor metal halide to cyclohexylphosphine ratio on the film properties was also undertaken. It was found that decreasing the moles of phosphine and increasing the moles of niobium $(\mathrm{V})$ chloride (by altering the respective bubbler temperatures) had no discernible effect on the composition of the resultant film as determined by EDAX in the $\mathrm{Nb} / \mathrm{P}$ gas phase molar ratio range $1 / 400000-1 / 12$. Glancing angle XRD analysis of the resultant films indicated that all were $\beta-\mathrm{NbP}$.

An experiment carried out at $550{ }^{\circ} \mathrm{C}$ with with identical precursor bubbler temperatures and flow rates to those shown in Table 1 but with a 1 minute run time deposited an extremely thin film with total substrate coverage. The film was too thin for practical analysis but was significantly less than $50 \mathrm{~nm}$ thick, as determined by cross sectional SEM. The growth rate at this temperature, determined from a 3 minute run time, would suggest a film thickness of $60 \mathrm{~nm}$ and therefore it seems likely that there is an induction period during which no significant film growth is observed.

SEM was used to examine the surface of the films formed from $\mathrm{NbCl}_{5}$ and $\mathrm{Cy}^{\text {hex }} \mathrm{PH}_{2}$ deposited at $400-600^{\circ} \mathrm{C}$ and in all cases a crazy-paving like surface was observed, consistent with an island-growth formation mechanism. All the films were adherent to the substrate (Scotch tape test). Films deposited above $500{ }^{\circ} \mathrm{C}$ were hard, being resistant to abrasion by brass and steel but the films deposited at $500{ }^{\circ} \mathrm{C}$ and below were abraded by a steel stylus. The films were very chemically resistant, withstanding immersion in DCM, ether, toluene and concentrated (16 M) nitric acid with no optical deterioration over several weeks. Concentrated $(12 \mathrm{M})$ hydrochloric acid dissolved the films over a period of a week.

\subsection{APCVD of $\mathrm{TaCl}_{5}$ and $\mathrm{Cy}^{\text {hex }} \mathrm{PH}_{2}$}

Results for the reactions of $\mathrm{TaCl}_{5}$ with $\mathrm{Cy}^{\text {hex }} \mathrm{PH}_{2}$ at various temperatures are summarised in Table 1 . At $600{ }^{\circ} \mathrm{C}$ the films formed were localised to the front half of the substrate but no discolouration was observed as seen for niobium. The films were again highly reflective but appeared more golden in colour than 
Table 2 CVD process conditions for the reaction of $\mathrm{VCl}_{4}$ or $\mathrm{VOCl}_{3}$ with $\mathrm{R}_{\mathrm{x}} \mathrm{PH}_{3-\mathrm{x}}$ (where $\mathrm{R}=\mathrm{Cy}$ hex and $\mathrm{x}=1,2$ or 3 or $\mathrm{R}=\mathrm{SiMe}_{3}$ where $\mathrm{x}=3$ )

\begin{tabular}{|c|c|c|c|c|c|c|c|c|c|}
\hline $\begin{array}{l}\text { Metal halide } \\
\text { precursor }\end{array}$ & Phosphine & $\begin{array}{l}\text { Metal halide } \\
\text { bubbler } \\
\text { temperature } \\
\left({ }^{\circ} \mathrm{C}\right)\end{array}$ & $\begin{array}{l}\text { Metal halide } \\
\text { bubbler } \mathrm{N}_{2} \\
\text { flow rate } \\
(1 / \mathrm{min})\end{array}$ & $\begin{array}{l}\text { Phosphine } \\
\text { bubbler } \\
\text { temperature } \\
\left({ }^{\circ} \mathrm{C}\right)\end{array}$ & $\begin{array}{l}\text { Phosphine } \\
\text { bubbler } \mathrm{N}_{2} \\
\text { flow rate } \\
(1 / \mathrm{min})\end{array}$ & $\begin{array}{l}\text { Metal halide/ } \\
\text { phosphine } \\
\text { ratio (mol) }\end{array}$ & $\begin{array}{l}\text { Substrate } \\
\text { temperature } \\
\left({ }^{\circ} \mathrm{C}\right)\end{array}$ & $\begin{array}{l}\text { Run time } \\
\text { (min) }\end{array}$ & $\begin{array}{l}\text { EDAX (V/P } \\
\text { ratio) }\end{array}$ \\
\hline $\mathrm{VCl}_{4}$ & $\mathrm{Cy}{ }^{\text {hex }} \mathrm{PH}_{2}$ & 100 & 0.3 & 130 & 0.3 & $1 / 5$ & 600 & 1 & 0.8 \\
\hline $\mathrm{VCl}_{4}$ & $\mathrm{Cy}{ }^{\text {hex }} \mathrm{PH}_{2}$ & 100 & 0.3 & 130 & 0.3 & $1 / 5$ & 500 & 1 & No Film \\
\hline $\mathrm{VCl}_{4}$ & $\mathrm{Cy}{ }^{\text {hex }} \mathrm{PH}_{2}$ & 100 & 0.3 & 130 & 0.3 & $1 / 5$ & 400 & 1 & No Film \\
\hline $\mathrm{VCl}_{4}$ & $\mathrm{Cy}{ }^{\text {hex }} \mathrm{PH}_{2}$ & 100 & 0.3 & 130 & 0.3 & $1 / 5$ & 300 & 1 & No Film \\
\hline $\mathrm{VCl}_{4}$ & $\mathrm{Cy}^{\text {hex }}{ }_{2} \mathrm{PH}$ & 60 & 0.3 & 200 & 1.6 & a & 600 & 2 & No Film \\
\hline $\mathrm{VCl}_{4}$ & $\mathrm{Cy}^{\text {hex }}{ }_{3} \mathrm{P}$ & 60 & 0.3 & 250 & 1.8 & a & 600 & 2 & No Film \\
\hline $\mathrm{VCl}_{4}$ & $\left(\mathrm{Me}_{3} \mathrm{Si}\right)_{3} \mathrm{P}$ & 40 & 0.3 & 200 & 0.4 & a & 600 & 3 & No Film \\
\hline $\mathrm{VOCl}_{3}$ & $\mathrm{Cy}{ }^{\text {hex }} \mathrm{PH}_{2}$ & 40 & 0.3 & 100 & 0.3 & $1 / 8$ & 600 & 2 & 0.7 \\
\hline $\mathrm{VOCl}_{3}$ & $\mathrm{Cy}{ }^{\text {hex }} \mathrm{PH}_{2}$ & 40 & 0.3 & 100 & 0.3 & $1 / 8$ & 500 & 2 & No Film \\
\hline $\mathrm{VOCl}_{3}$ & $\left(\mathrm{Me}_{3} \mathrm{Si}\right)_{3} \mathrm{P}$ & 30 & 0.2 & 200 & 0.4 & a & 600 & 2 & 0.6 \\
\hline $\mathrm{VOCl}_{3}$ & $\left(\mathrm{Me}_{3} \mathrm{Si}\right)_{3} \mathrm{P}$ & 30 & 0.2 & 200 & 0.4 & a & 500 & 3 & No Film \\
\hline
\end{tabular}

${ }^{a}$ Phosphine vapour pressures unknown.

the niobium films. The average $\mathrm{Ta} / \mathrm{P}$ composition determined using EDAX was $\mathrm{TaP}_{1.4}$ and no chlorine contamination was observed. Glancing angle XRD showed that the only crystalline phase present in a film was $\beta$-TaP. ${ }^{16}$ The films were between 370 and $400 \mathrm{~nm}$ thick at the centre of the substrate $(\sim 130$ $\mathrm{nm} / \mathrm{min}$ growth rate) and had a room temperature resistivity of $3000 \mu \Omega \mathrm{cm}^{-1}$, almost identical to that of the NbP films. Cooling the films to $-197{ }^{\circ} \mathrm{C}$ decreased the resistivity by more than $30 \%$, again indicating metallic-like behaviour at the temperatures examined.

The films formed at a substrate temperature of $550{ }^{\circ} \mathrm{C}$ showed total substrate coverage, were gold in reflection and had an average $\mathrm{TaP}_{1.3}$ composition by EDAX with no chlorine contamination. A sample film indexed as $\beta-\mathrm{TaP}$, as shown in Figure 3, with unit cell $a=3.33(3) \AA, c=11.6(2) \AA$ (literature $a$ $=3.330 \AA, c=11.39 \AA) .{ }^{17}$ The large, very broad absorbtion at $25-40^{\circ} 2 \theta$ is due to the amorphous glass substrate) The films were $\sim 300 \mathrm{~nm}$ thick $(\sim 100 \mathrm{~nm} / \mathrm{min})$ with a room temperature resistivity of $6000 \mu \Omega \mathrm{cm}^{-1}$.

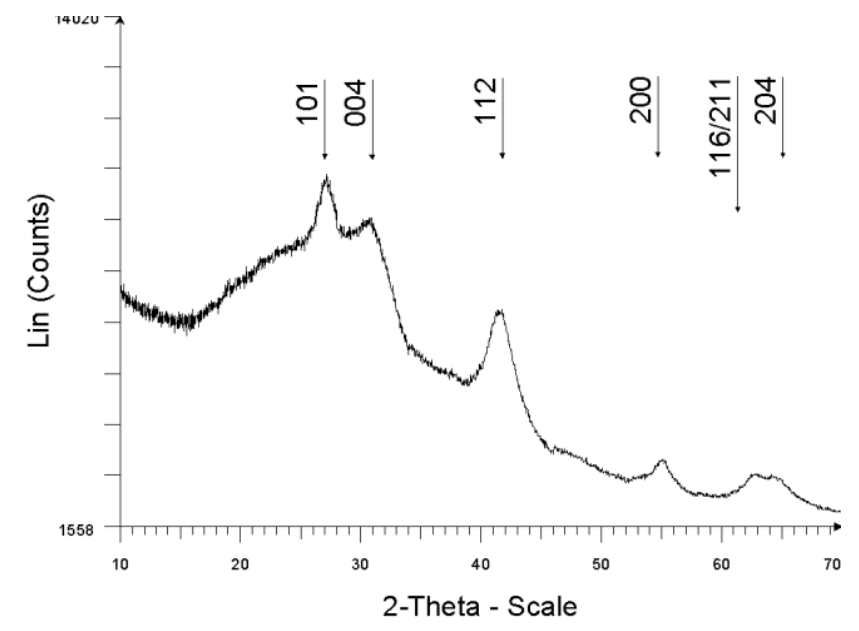

Fig. 3 XRD pattern of TaP film deposited at $550{ }^{\circ} \mathrm{C}$.

At $400{ }^{\circ} \mathrm{C}$ a very thin film was deposited covering only a small part of the substrate. No meaningful analysis could be obtained from films deposited at this temperature.

XPS analysis of a film deposited at $550{ }^{\circ} \mathrm{C}$ showed that after etching through the surface contamination layer there was no detectable carbon or chlorine contamination. The P $2 p$ ionisation was centred on a binding energy of $128.6 \mathrm{eV}$, which is indicative of a transition metal phosphide. ${ }^{17} \mathrm{~A}$ small $\mathrm{P} 2 \mathrm{p}$ ionisation at
$133.4 \mathrm{eV}$ was also visible in the first two argon ion etched layers, indicative of oxygen contamination in the form of phosphate. ${ }^{10}$ Also in the first two etched layers only an $\mathrm{O} 1 \mathrm{~s}$ ionisation was observed at $530.8 \mathrm{eV}$ but this was evidently formed from two separate peaks. The Ta $4 \mathrm{f}$ showed a set of major peaks with $\mathrm{Ta} 4 \mathrm{f}_{7 / 2}$ at $21.8 \mathrm{eV}$ and $\mathrm{Ta} 4 \mathrm{f}_{5 / 2} 23.6 \mathrm{eV}$ with minor peaks observed with $\mathrm{Ta} 4 \mathrm{f}_{7 / 2}$ at $26.2 \mathrm{eV}$ and $\mathrm{Ta} 4 \mathrm{f}_{5 / 2}$ at $28.0 \mathrm{eV}$ in the first two etched layers. In $\mathrm{Ta}_{2} \mathrm{O}_{5}$ the $\mathrm{O} 1 \mathrm{~s}$ peak appears at $530.4 \mathrm{eV}^{19}$ and the $\mathrm{Ta} 4 \mathrm{f}_{7 / 2}$ peak at $26.8 \mathrm{eV} .{ }^{20}$ Again this indicates the oxygen contamination is as a result of postreaction oxidation.

SEM of the films formed at substrate temperatures of $400-600$ ${ }^{\circ} \mathrm{C}$ showed a crazy-paving like surface in all cases. All the films were adherent to the substrate and hard, resisting abrasion by brass and steel stylus. The films were extremely chemically resistant showing no change to common solvents or concentrated acids (nitric and hydrochloric) over several weeks immersion.

\subsection{APCVD of $\mathrm{VCl}_{4}$ and $\mathrm{Cy}^{\text {hex }} \mathrm{PH}_{2}$}

The conditions used for the reaction of $\mathrm{VCl}_{4}$ with various phosphines are shown in Table 2 . At $600{ }^{\circ} \mathrm{C}$ with a gas phase

$\mathrm{VCl}_{4} / \mathrm{Cy}^{\text {hex }} \mathrm{PH}_{2}$ mole ratio of $1 / 5$ film deposition took place. The films were black with a gold sheen and substrate coverage was extremely limited $\left(\sim 4 \mathrm{~cm}^{3}\right)$ to the hottest (central) part of the substrate. Film formation was not entirely reproducible with some deposition experiments utilising identical conditions not yielding films. EPMA analysis of a sample film showed that the film had negligible chlorine contamination and an almost constant metal-rich surface composition of $\mathrm{V}_{1.7} \mathrm{P}$ across a distance of $8000 \mu \mathrm{m}$.

XPS analysis of a film deposited at $600{ }^{\circ} \mathrm{C}$ showed that the surface had only one surface phosphorus environment, at 131.2 $\mathrm{eV}$. This value is too high for VP $(\mathrm{P} 2 \mathrm{p}=129.1 \mathrm{eV}){ }^{8}$ The surface vanadium environment $\mathrm{V} 2 \mathrm{p}_{3 / 2}=518.3 \mathrm{eV}$ matches the value determined for vanadium in $\mathrm{VOPO}_{4}{ }^{21}$ but is too high for $\mathrm{VO}_{2}^{22}$ or $\mathrm{V}_{2} \mathrm{O}_{5}{ }^{23}\left(\mathrm{~V} 2 \mathrm{p}_{3 / 2} \approx 516 \mathrm{eV}\right)$. The surface $\mathrm{O} 1 \mathrm{~s}$ ionisation was broad and centred on $532 \mathrm{eV}$. The results suggest the surface is phosphate terminated, with little oxide or phosphide present. After etching the $\mathrm{P} 2 \mathrm{p}$ peak observed at $131.2 \mathrm{eV}$ shifted to higher energy ( $\mathrm{P} 2 \mathrm{p}=132.6 \mathrm{eV}$ ) but almost disappeared with the major peak observed being P $2 p=129.2 \mathrm{eV}$, corresponding to VP. ${ }^{18}$ After etching the vanadium peaks had poor shape with the major peak at $\mathrm{V} 2 \mathrm{p}_{3 / 2}=512.3 \mathrm{eV}$ and minor peaks at $\mathrm{V} 2 \mathrm{p}_{3 / 2}$ $=517.7 \mathrm{eV}$ and $\mathrm{V} 2 \mathrm{p}_{3 / 2}=518.9 \mathrm{eV}$. The $\mathrm{O} 1 \mathrm{~s}$ peak was extremely broad spanning $8 \mathrm{eV}$ centred on $\mathrm{O} 1 \mathrm{~s}=531.4 \mathrm{eV}$. Although the $\mathrm{P} 2 \mathrm{p}$ and $\mathrm{V} 2 \mathrm{p}_{3 / 2}$ ionisations are consistent with the formation of VP there are also vanadium ionisations consistent 
with the formation of oxide and therefore it is thought the bulk composition of this sample is a composite of vanadium phosphide, vanadium oxide and vanadium phosphate.

At temperatures below $600{ }^{\circ} \mathrm{C}$ no deposition was observed under any conditions from reaction of $\mathrm{VCl}_{4}$ and $\mathrm{Cy}^{\text {hex }} \mathrm{PH}_{2}$.

Measurement of film thickness for one of the films formed from $\mathrm{VCl}_{4} / \mathrm{Cy}^{\text {hex }} \mathrm{PH}_{2}$, using end-on SEM, showed the film was $550 \mathrm{~nm}$ thick $(550 \mathrm{~nm} / \mathrm{min})$. The film resistivity was $4000 \mu \Omega \mathrm{cm}^{-1}$, which is equivalent to the $\mathrm{NbP}$ and $\mathrm{TaP}$ films and comparable to that of the bulk powder $\left(9700 \mu \Omega \mathrm{cm}^{-1}\right){ }^{1}$ SEM of the film surface showed a crazy-paving like morphology. The films were adherent to the substrate, were not abraded by a brass stylus but were scratched with a steel stylus. The films were not as chemically resistant as either the $\mathrm{NbP}$ or $\mathrm{TaP}$ films; although they survived immersion in common solvents (DCM, toluene, ether) they were rapidly stripped by both concentrated nitric and hydrochloric acids (1 day immersion).

\subsection{APCVD of $\mathrm{VCl}_{4}$ and $\mathrm{Cy}^{\text {hex }}{ }_{2} \mathrm{PH}, \mathrm{Cy}^{\text {hex }}{ }_{3} \mathrm{P}$ or $\left(\mathrm{Me}_{3} \mathrm{Si}\right)_{3} \mathrm{P}$}

The reaction of $\mathrm{VCl}_{4}$ with various other phosphines was also examined because of the limited success of the $\mathrm{VCl}_{4} / \mathrm{Cy}^{\text {hex }} \mathrm{PH}_{2}$ system. It has been reported that the reaction of $\mathrm{TiCl}_{4}$ with $\mathrm{Cy}_{2}^{\text {hex }}{ }_{2} \mathrm{PH}$ and $\mathrm{Cy}^{\text {hex }}{ }_{3} \mathrm{P}$ can yield films of $\mathrm{TiP}^{24}$ and therefore the reaction of $\mathrm{VCl}_{4}$ and these phosphines was examined. Under conditions similar to those used in Table 2 no deposition was observed over a series of experiments. The conditions shown are for the experiments undertaken which were most likely to yield thin films, i.e. highest substrate temperature and highest phosphine flow (phosphine bubbler temperature). However, despite this, no film could be obtained from the reaction of $\mathrm{VCl}_{4}$ with $\mathrm{Cy}_{2}^{\text {hex }}{ }_{2} \mathrm{PH}$ or $\mathrm{Cy}_{3}^{\text {hex }} \mathrm{P}$.

The reaction of $\mathrm{VCl}_{4}$ with $\left(\mathrm{Me}_{3} \mathrm{Si}\right)_{3} \mathrm{P}$ was also examined; $\left(\mathrm{Me}_{3} \mathrm{Si}\right)_{3} \mathrm{P}$ has been found to provide a route to high quality films of TiP from reaction with $\mathrm{TiCl}_{4}{ }^{25}$ The reaction was speculated to be via elimination of trimethylsilylchloride (Eqn 1).

$3 \mathrm{TiCl}_{4}+4\left(\mathrm{Me}_{3} \mathrm{Si}\right)_{3} \mathrm{P} \longrightarrow 3 \mathrm{TiP}+12 \mathrm{Me}_{3} \mathrm{SiCl}+\mathrm{P}$

[Eqn 1]

The conditions chosen were identical to those used successfully for the production of TiP from $\mathrm{TiCl}_{4}$ and $\left(\mathrm{Me}_{3} \mathrm{Si}\right)_{3} \mathrm{P}$. Despite this no deposition was observed and the values shown in Table 2 are for the highest substrate temperature and highest phosphine bubbler temperature used.

\section{$3.5 \mathrm{VOCl}_{3}+\mathrm{Cy}^{\text {hex }} \mathrm{PH}_{2}$}

Due to the difficulties encountered in reliably depositing thin films using $\mathrm{VCl}_{4}$ a number of reactions utilising $\mathrm{VOCl}_{3}$ were carried out. The reaction of $\mathrm{VOCl}_{3}$ with $\mathrm{Cy}^{\text {hex }} \mathrm{PH}_{2}$ at $600{ }^{\circ} \mathrm{C}$ yielded black/gold films which were localised to a small $(\sim 2$ $\mathrm{cm}^{3}$ ) central (hottest) area of the substrate. EDAX measurements gave an average composition of $\mathrm{VP}_{1.3}$. EPMA analysis of a sample film produced at $600{ }^{\circ} \mathrm{C}$ showed the film to be even across a surface distance of $5000 \mu \mathrm{m}$ with an almost fixed composition of $\mathrm{V}_{1.3} \mathrm{P}$ whilst chlorine contamination was again negligible $(<1$ at. $\%)$. The films were amorphous as determined by glancing angle XRD.

XPS analysis of a film deposited at $600{ }^{\circ} \mathrm{C}$ showed a phosphate terminated surface (V 2 $\left.\mathrm{p}_{3 / 2} 518.4 \mathrm{eV}, \mathrm{P} 2 \mathrm{p} 133.2 \mathrm{eV}\right)$. Etching removed surface carbon and chlorine contamination. The bulk films, after argon ion etching, consisted of a phosphorus ionisation at $\mathrm{P} 2 \mathrm{p}=129.2 \mathrm{eV}$ and $\mathrm{V} 2 \mathrm{p}_{3 / 2}=512.8 \mathrm{eV}$. These values match literature values for VP extremely well (P 2p 129.1 $\left.\mathrm{eV}, \mathrm{V} 2 \mathrm{p}_{3 / 2} 512.6 \mathrm{eV}\right)$. A minor peak was observed for $\mathrm{P} 2 \mathrm{p}=$ $134.2 \mathrm{eV}$ and the $\mathrm{V} 2 \mathrm{p}_{3 / 2}$ peak had a shoulder at $514.4 \mathrm{eV}$. An O $1 \mathrm{~s}$ peak at $531.2 \mathrm{eV}$ was observed in all levels but decreased significantly with etching. These data are interpreted as being due to a bulk composition of VP, oxidised to phosphate at the surface with some minor oxide contamination present. Due to the decreasing oxide contamination with etching it is thought the oxide is present through post-reaction oxidation as opposed to being due to the vanadium bound oxygen not being removed during the CVD process. End-on SEM showed that a sample film was $750 \mathrm{~nm}$ thick and resistivity measurements gave a value of $2000 \mu \Omega \mathrm{cm}^{-1}$. The films were rapidly digested by concentrated acids but were resistant to common solvents.

At temperatures below $600{ }^{\circ} \mathrm{C}$ no deposition was observed from reaction of $\mathrm{VOCl}_{3}$ and $\mathrm{Cy}^{\text {hex }} \mathrm{PH}_{2}$.

\section{$3.6 \mathrm{VOCl}_{3}+\left(\mathrm{Me}_{3} \mathrm{Si}\right)_{3} \mathrm{P}$}

The reaction of $\mathrm{VOCl}_{3}$ with $\left(\mathrm{Me}_{3} \mathrm{Si}\right)_{3} \mathrm{P}$ was also examined. The primary problem envisaged with the use of $\mathrm{VOCl}_{3}$ with $\mathrm{Cy}^{\text {hex }} \mathrm{PH}_{2}$ was the lack of an obvious elimination pathway for the vanadium bound oxygen. It was thought that the use of tristrimethylsilylphosphine might allow elimination through the formation of a strong silicon-oxygen bond. In reactions between $\mathrm{VOCl}_{3}$ and $\left(\mathrm{Me}_{3} \mathrm{Si}\right)_{3} \mathrm{P}$ at substrate temperatures of $600{ }^{\circ} \mathrm{C}$ very thin (relative to the reaction between $\mathrm{VOCl}_{3}$ and $\mathrm{Cy}{ }^{\text {hex }} \mathrm{PH}_{2}$ ) black/gold films with limited coverage $\left(\sim 1 \mathrm{~cm}^{3}\right)$ were deposited. EPMA analysis of a sample showed the film to be much less even than that observed in previous samples, with the vanadium and phosphorus atomic percentages changing dramatically between analysis points. A small amount of chlorine contamination was observed in these samples $(\sim 1-2$ at.\%). The $\mathrm{V}_{1.4} \mathrm{P}$ although some variation was observed across the surface. No XPS analysis was attempted. The films were too thin to be able to determine the thickness using end-on SEM. Film resistivity measurement showed the films were metallic conductors. Chemical resistance of the films was equivalent to VP films deposited using $\mathrm{Cy}^{\text {hex }} \mathrm{PH}_{2}$.

No films were deposited from the reaction of $\mathrm{VOCl}_{3}$ and $\left(\mathrm{SiMe}_{3}\right)_{3} \mathrm{P}$ at substrate temperatures below $600{ }^{\circ} \mathrm{C}$.

\section{Discussion}

The APCVD reaction of $\mathrm{MCl}_{5}$ (where $\mathrm{M}=\mathrm{Nb}$, Ta) with $\mathrm{Cy}^{\text {hex }} \mathrm{PH}_{2}$ deposits thin films of crystalline $\beta$-MP at substrate temperatures of $550{ }^{\circ} \mathrm{C}$ and above. At substrate temperatures of $400{ }^{\circ} \mathrm{C}$ and above deposition of amorphous metal phosphide films is observed. Changing the gas phase metal/phosphorus molar ratio had no discernible effect on the film composition or microstructure. The films were metallic and chemically resistant. The films had chlorine contamination below the detection limit of the analysis techniques used $(<1$ at. \%), indicating that the use of $\mathrm{Cy}^{\text {yhex }} \mathrm{PH}_{2}$ provides a facile elimination route for the metalbound halide. Oxygen contamination was surface limited showing that it was as a result of post-reaction oxidation. The phosphide was oxidised to phosphate and oxide and it may be this that gives the thin films their excellent chemical resistance. It should be noted that the surface oxidation effectively forms a passivation layer and oxidation does not proceed beyond the first few atomic layers.

The APCVD reaction of $\mathrm{VCl}_{4}$ with $\mathrm{Cy}^{\text {hex }} \mathrm{PH}_{2}$ deposited films of vanadium phosphide at temperatures of $600{ }^{\circ} \mathrm{C}$. However the reaction did not reliably produce films. Initially it was thought that this may have been related to the temperature of reaction and also very rapid pre-reaction of the precursors. When deposition took place it was observed in the centre part of the substrate, an area which was found to be up to $25^{\circ} \mathrm{C}$ hotter than the edges of the substrate. The reactor used is limited for use at $600{ }^{\circ} \mathrm{C}$ (the glass substrates begin to soften above this temperature) and therefore no higher temperature runs were attempted. However, another causal factor is thought to be the quality of the $\mathrm{VCl}_{4}$ used for reaction. When deposition was 
observed, repeat experiments utilising identical conditions, carried out immediately after an initial deposition reaction would also yield films. If the bubbler was not recharged for several days, or if a new batch of $\mathrm{VCl}_{4}$ was used to recharge the bubbler the same conditions would often not yield films.

Observations made during the APCVD reaction of $\mathrm{VCl}_{4}$ and ${ }^{C y}{ }^{\text {hex }} \mathrm{PH}_{2}$ showed a thick purple smoke was produced in the bypass exhaust. Solution phase experiments in which $\mathrm{VCl}_{4}$ and Cy ${ }^{\text {hex }} \mathrm{PH}_{2}$ were mixed yielded a purple solid but analysis showed that this was not an adduct of the type formed between the reaction of $\mathrm{TiCl}_{4}$ and $\mathrm{Cy}^{\text {hex }} \mathrm{PH}_{2} \cdot{ }^{26}$ Low pressure CVD experiments using the solution-phase produced purple-solid showed no deposition up to $550{ }^{\circ} \mathrm{C}$ and it was concluded that it was not a suitable single-source precursor for low temperature thin film formation. This again may indicate that the temperature required to deposit films of vanadium phosphide from the product of reaction between $\mathrm{VCl}_{4}$ and $\mathrm{Cy}^{\text {hex }} \mathrm{PH}_{2}$ is greater than seen for the reaction between $\mathrm{TiCl}_{4}$ and $\mathrm{Cy}^{\text {hex }} \mathrm{PH}_{2}{ }^{12}$

The difference between the film composition determined by EDAX and EPMA analysis has been attributed to the phosphorus and silicon lines being almost coincident in the EDAX spectrum. A further observation shows that the composition, as determined using EPMA, changes from slightly phosphorus rich $\left(\mathrm{NbP}_{1.1}\right)$ to metal rich $\left(\mathrm{V}_{1.7} \mathrm{P}\right)$. This could be interpreted as being due to a difference in phase, i.e. NbP compared to $\mathrm{V}_{3} \mathrm{P}_{2}$ (or mixture of $\mathrm{VP}$ and $\left.\mathrm{V}_{2} \mathrm{P}\right)$. However this difference is ascribed to different levels of oxidation in the deposited films. In the films deposited with $\mathrm{NbP}_{1.1}$ almost no oxidation was detected using XPS, and the oxidation present was extremely surface limited. In the films with a metal-rich stoichiometry $\left(\mathrm{V}_{1.3} \mathrm{P}\right.$ and above $)$ oxidation on the surface was severe and although decreased after etching was still present in the bulk as determined using XPS. This means that in the 'VP' film the EPMA result is a composite of, say, VP $+\mathrm{VO}_{\mathrm{x}}$ which would increase the metal/phosphorus ratio observed. Interestingly less oxygen contamination was observed in the VP film deposited from $\mathrm{VOCl}_{3}$ and $\mathrm{Cy}^{\text {hex }} \mathrm{PH}_{2}$ than in the film deposited from $\mathrm{VCl}_{4}$ and $\mathrm{Cy}^{\text {hex }} \mathrm{PH}_{2}$.

From the XPS results the order of oxidation observed was $\beta$ $\mathrm{NbP} \approx \beta-\mathrm{TaP}<<\mathrm{VP}$. Both the $\mathrm{NbP}$ and $\mathrm{TaP}$ showed extremely surface limited oxidation whereas the VP showed much more extensive contamination extending further down into the film. This result is consistent with the findings of Ripley on bulk powders $^{1}$ and Motojima on films of metal phosphides. ${ }^{2}$

\section{Conclusion}

In conclusion this paper reports straight forward routes to Group $\mathrm{Vb}$ MP coatings. The reaction of $\mathrm{MCl}_{5}$ (where $\mathrm{M}=\mathrm{Nb}$ or Ta) with $\mathrm{Cy}^{\text {hex }} \mathrm{PH}_{2}$ provides a facile route to crystalline films of $\beta$ $\mathrm{MP}$ at temperatures of $550{ }^{\circ} \mathrm{C}$ and above. The reaction of $\mathrm{VCl}_{4}$ and $\mathrm{VOCl}_{3}$ with $\mathrm{R}_{\mathrm{x}} \mathrm{PH}_{3-\mathrm{x}}$ (where $\mathrm{R}=\mathrm{Cy}^{\text {hex }}$ and $\mathrm{x}=1,2$ or 3 or $\mathrm{R}$ $=\mathrm{Me}_{3} \mathrm{Si}$ and $\mathrm{x}=3$ ) deposits highly localised films of amorphous vanadium phosphide at $600{ }^{\circ} \mathrm{C}$. The films are highly reflective and stable to a wide range of chemical reagents. The oxidation of the $\mathrm{NbP}$ and $\mathrm{TaP}$ films are surface limited (no change after 6 months storage in air). In all of the systems studied the rate of deposition was temperature dependent. This, coupled with the good film coverage of $\mathrm{NbP}$ and $\mathrm{TaP}$, indicates a surface-reaction rate controlled CVD process.

\section{Acknowledgements}

The EPSRC is thanked for grant GR/M98623 (I.P. Parkin and C.J. Carmalt). C.J.C. is also grateful to the Royal Society for a Dorothy Hodgkin fellowship and research grant. Kevin Reeves of UCL archaeology is thanked for the EPMA results. Pilkington Glass are thanked for the supply of substrates and Epichem Ltd for phosphine and metal precursor supplied for other work within this grant.

\section{References}

1 R. L. Ripley, J. Less-Common Met., 1962, 4, 496

2 S. Motojima, T. Wakamatsu, K. Sugiyama, J. Less-Common Met., 1981, 82, 379.

3 K. Komaki, JP2248079, 1990.

4 C. E. Myers, High Temp. Sci., 1974, 6, 309

5 A. L. Hector, I. P. Parkin, J. Mater. Chem., 1994, 4, 279.

6 K. Hieber, Thin Solid Films, 1974, 24, 157.

7 T. Takashi, H. Itoh, T. Yamaguchi, J. Cryst. Growth, 1979, 46, 69.

8 G. Oya, Y. Onodera, J. Appl. Phys., 1974, 45, 1389.

9 I. P. Parkin, G. S. Elwin, J. Mater. Chem., 2001, 11, 3120.

10 J. T. Scheper, K. C. Jayaratne, L. M. Liable-Sands, G. P.A. Yap, A. L. Rheingold, C. H. Winter, Inorg. Chem., 1999, 38, 4354.

11 C. S. Blackman, C. J. Carmalt, I. P. Parkin, S. A. O’Neill, K. C. Molloy, L. Apostolico, J. Mater. Chem., 2001, 11, 2408.

12 C. S. Blackman, C. J. Carmalt, I. P. Parkin, S. A. O’Neill, K. C. Molloy, L. Apostolico, Chem. Mater., 2002, 14, 3167.

13 R. G. Binions, C. S. Blackman, C. J. Carmalt, I. P. Parkin, S. A. O’Neill, K. C. Molloy, L. Apostolico, Polyhedron, 2002, 21, 1943.

14 C. S. Blackman, C. J. Carmalt, T. D. Manning, I. P. Parkin, S. A. O’Neill, K. C. Molloy, L. Apostolico, Chem. Vap. Dep., 2003, 9, 10.

15 C. S. Blackman, C. J. Carmalt, I. P. Parkin, S. A. O’Neill, K. C. Molloy, L. Apostolico, Materials Letters, In Press.

16 G. Becker, H. Schmidt, G. Uhl, W. Uhl, Inorg. Synth., 1990, 27, 243.

17 N. Schönberg, Acta Chem. Scand., 1954, 8, 226.

18 C. E. Myers, H. F. Franzen, J. W. Anderegg, Inorg. Chem., 1985, 24, 1822.

19 V. I. Nefedov, D. Gati, B. F. Dzurinskii, N. P. Sergushin, Ya. V. Salyn, Russ. J. Inorg. Chem., 1975, 20, 2307.

20 G. E. Mcguire, G. K. Scweitzer, T. A. Carlson, Inorg. Chem., 1973, 12, 2450 .

21 M. Abon, K. E. Bere, A. Tuel, P. Delichere, J. Catal., 1995, 156, 28.

22 T. Christmann, B. Felde, W. Niessner, D. Scalch, A. Scharmann, Thin Solid Films, 1996, 287, 134.

23 M. N. Field, I. P. Parkin, J. Mater. Chem., 2000, 10, 1863.

24 C. S. Blackman, C. J. Carmalt, I. P. Parkin, S. A. O’Neill, K. C. Molloy, L. Apostolico, Proceedings EUROCVD XIV, Paris, France, April $27^{\text {th }}$-May $2^{\text {nd }}, 2003$, Accepted for publication.

25 C. S. Blackman, C. J. Carmalt, I. P. Parkin, S. A. O’Neill, K. C. Molloy, L. Apostolico, Applied Surface Science, Accepted for publication.

26 C. S. Blackman, C. J. Carmalt, I. P. Parkin, S. A. O’Neill, K. C. Molloy, L. Apostolico, J. Chem. Soc. Dalton Trans., 2002, 270 
